\title{
Gloomy prospects face biodiversity treaty
}

Washington. As delegates prepare to meet next week in the Bahamas to negotiate details of the international Convention on Biological Diversity, signatories to the treaty, approved by the Earth Summit in Rio de Janeiro in 1992, remain as divided as ever on several important issues.

These range from how the convention should be funded to the possible implications of a bid to impose a moratorium on trade in genetically engineered plants and animals. Furthermore, with the United States still putting off ratifying the treaty, the prospects for settling those issues appear worse than at any time since the convention came into being.

President Bill Clinton signed the biodiversity treaty last year. But the Senate failed to ratify it, leaving the United States as merely a non-voting 'observer' at the Bahamas meeting. So far, 167 countries have signed the convention and 97 have ratified it, including all the other major industrial nations.

Much of the business at this first conference of parties, which runs from 28 November to 9 December, will be administrative, setting up rules and procedures. But the signatories will also face some of the divisive issues that have so far been avoided through vague wording of the treaty -- such as the transfer of technology to developing nations, and the sharing of patent royalties for products developed from native biological resources.

The agreed interim funding mechanism is the Global Environment Facility (GEF), administered by the World Bank. The United States and other industrial nations would like to make that arrangement permanent. But many developing nations, who want a greater say in which projects receive fund-

committee and due to be ratified by the IUPAC Council at its meeting in Guildford, England, next year, are bohrium, hahnium and meitnerium respectively.

"The discovers have the right to name an element, and IUPAC can accept it or not," says Armbruster. "But if they don't, they should tell you and allow you to come up with another name, not invent another name themselves."

The group are particularly unhappy because they wanted to honour Lise Meitner, who worked with Otto Hahn. He was awarded the Nobel prize for chemistry in 1944 for their joint work on the discovery of the fission of heavy nuclei. But Meitner received nothing and her contribution to the work is generally overlooked. The group did not want the names to be used for adjacent elements.

Their dissatisfaction is echoed by Albert Ghiorso, senior nuclear scientist ing, are likely to resist.

Intergovernmental meetings held over the past two years to lay the groundwork for next week's conference have made little progress in deciding what kinds of projects should even be funded. They have agreed on easy projects, such as taking biological invento-

\section{IMAGE UNAVAILABLE FOR COPYRIGHT REASONS}

Still at issue: how to fund projects aimed at preserving genetic resources.

ries. But they have argued over how and where conservation programmes should be set up - for example, whether money should be spent preserving known 'hot spots' of biodiversity, or be more evenly distributed between countries

Another potentially explosive issue is 'bio-safety' - the purported danger of introducing genetically engineered organisms into the natural environment. Even though the matter is not on the agenda, several nations including India, as well as a number of environmental groups, want to raise it.

Richard Godown, a senior vicepresident at the US Biotechnology Industry Organization, which represents the interests of biotechnology companies, says that he does not believe a moratorium on trade in genetically engineered plants and animals

emeritus at LBL, and leader of the team that discovered element 106. "The right of discoverers to name elements is sacrosanct," says Ghiorso.

In view of the current dispute, the German group has decided not to propose a name for the new element. It says that it has sent a letter to IUPAC explaining its disagreement with the way the earlier elements were named and that it will "do everything" it can to force IUPAC to reconsider its proposals before the ratification meeting in Guildford.

Ghiorso is confident that, faced with widespread opposition, the IUPAC will back down. And he, for one, will continue to call the elements by the names suggested by their discoverers: rutherfordium (104), hahnium (105), seaborgium (106), nielsbohrium (107), hassium (108) and meitnerium (109).

Maggie Verrall will be agreed. But he describes it as a "dangerous idea to have floating around" at the Bahamas meeting.

Concern about such potential restrictions has fuelled US opposition to the biodiversity convention. Conservative Republicans in particular cite the treaty's vagueness on protecting intellectual property rights, and possible - though some say unlikely -restrictions on private property owners, as reasons not to sign.

Following the recent Republican congressional victories, the committee that oversees ratification of the treaty will now be chaired by one of its most vigorous opponents, Senator Jesse Helms of North Carolina. Republican opponents such as Helms are gambling that, even if the United States does not participate as a formal voting member, it will still wield influence at next week's meeting through its position as the largest donor to the GEF. As a Republican policy paper written in September says, "if the United States has so little support from its friends that no one will assist [it] by objecting to consensus on issues adverse to our interests, then the [Clinton] Administration had no business signing this convention".

But US reluctance to ratify may also encourage developing nations to pursue their own agendas at the meeting. Even if the United States dropped out of the convention, the GEF would still amount to some $\$ 1.5$ billion, nearly half of which would be used for programmes under the biodiversity convention.

Many US conservationists and biologists say the United States will be the loser if it chooses not to ratify. "The United States lost an amazing amount by not signing the convention early," says Daniel Janzen of the University of Pennsylvania. Now, he claims, US researchers are viewed with suspicion when they go prospecting for biological resources in other countries.

Godown agrees, and warns that if the United States does not sign, developing countries may choose to work instead with biotechnology companies from countries that have agreed to accept its rules.

An indication of the tensions likely to surface at next week's meeting have already come from the Convention on International Trade in Endangered Species (CITES) that ended last week in Florida, and which saw fireworks over, among other issues, proposed new criteria for listing species as protected.

The US delegation successfully fended off an attempt to apply rigid - and scientifically unjustifiable - numerical criteria on population size and size of habitat that would have allowed trade in certain whales, apes, and other species.

Tony Reichhardt 